\title{
Kenya in Turmoil: Post-Election Violence and Precarious Pacification
}

Jérôme Lafargue and Musambayi Katumanga

\section{(2) OpenEdition}

Electronic version

URL: https://journals.openedition.org/eastafrica/665

DOI: $10.4000 /$ eastafrica.665

ISSN: 2790-1076

Publisher

IFRA - Institut Français de Recherche en Afrique

Printed version

Date of publication: 1 April 2008

Number of pages: 11-32

ISSN: 2071-7245

\section{Electronic reference}

Jérôme Lafargue and Musambayi Katumanga, "Kenya in Turmoil: Post-Election Violence and Precarious Pacification", Les Cahiers d'Afrique de l'Est / The East African Review [Online], 38 | 2008, Online since 19 July 2019, connection on 09 December 2021. URL: http://journals.openedition.org/ eastafrica/665 ; DOl: https://doi.org/10.4000/eastafrica.665

This text was automatically generated on 9 December 2021.

Les Cahiers d'Afrique de l'Est / The East African Review 


\section{Kenya in Turmoil: Post-Election Violence and Precarious Pacification}

Jérôme Lafargue and Musambayi Katumanga

\section{Introduction}

1 The announcement of the presidential poll results caused a massive outpouring of violence It led to the loss of several hundred human lives and forced a tens of thousands others to flee their homes. These events cast light on the multiple problems (social controversy, political sclerosis, land inequalities and escalating crime in the society) that Kenya faces as a State.

2 Is Kenya a country of illusions and shortcuts? Praised just a short while ago for its political stability and economic growth, everything was disrupted in the last few days of 2007: election rigging, police repression, hard-line positions by cliques, information blackout, bloody settling of scores, reactivation of ethnic tensions, political assassinations, destruction of property, deaths by the hundreds... there is little missing from the panoply of a continent in crisis. The daily life of Kenyans was disrupted. Political conflict, social revolt and the crystallization of ethnic rivalries combined with growing opportunistic crime in a worrying trend. A brief look at these events will be followed by an attempt to understand the far-reaching failings in Kenya's history and society which some leading political players embraced, perhaps for the worst.

\section{Outbursts: increased forms of violence}

In Kenya there is a tradition of political violence, be it State-sponsored or private, which climaxes during elections, especially since the inception of multiparty politics in 1991. The use of ethnicity in political debate and in social relations, both as inwardlooking censure and a means of renegotiating social relations, brings about tensions at 
the height of these instances. The face-off over the presidency between a Kikuyu, outgoing President Mwai Kibaki, and a Luo, Raila Odinga, who hails from one of the country's two main ethnic communities, ${ }^{1}$ led to fears of excesses.

The election campaigns were verbally very virulent and shortly after the nominations for parliamentary elections, human rights organizations in Kenya denounced the instances of intimidation and murder. The agitation served as some sort of preelectoral "ritual," which leads to its fair share of deaths during every election period. All the same, the voters kept their votes, localising democratic deadline better than their political elite, who yielded to their old habits.

On 30 December 2007, after three days of uncertainty, the Electoral Commission of Kenya (ECK) Chairman, Samuel Kivuitu, announced Kibaki's re-election amidst chaos. ${ }^{2}$ From the unofficial figures regularly communicated by the media, many expected a win by Odinga, who was leading by several hundred thousand votes after the second round of counting. However, votes from Central Province and North Eastern Province, which were favourable to Kibaki, were yet to be counted. Last-minute manipulations toppled over all this. ${ }^{3}$ Soon after the announcement of the results, Nairobi was engulfed in violence, especially the slums that heavily supported Odinga, along with several big towns in the Rift Valley (Eldoret), Nyanza (Kisumu) and Coast Province (Mombasa) ${ }^{4}$. After several tempestuous days, during which the violence reached its peak on 3 January 2008, hundreds of deaths and tens of thousands of displaced persons were reported. ${ }^{5}$ The violence paralysed the country's economy ${ }^{6}$ and revived ethnic tensions that had been largely dormant.

6 There seemed to be evidence of election rigging by the government using various mechanisms. ${ }^{7}$ To a lesser extent ODM also seemed to have participated in rigging. Popular vindication built up as more and more signs of manipulation were denounced by ODM as well as European Union and Commonwealth observers, followed by local NGOs and some ECK commissioners. ${ }^{8}$

7 News and rumours about the rigging sparked off events. ${ }^{9}$ More than the ethnic affiliation of the suspected frauds in the elections, it is the disgust over their political strategy that fuelled the riots. Although the chaos started off as a political conflict (which could be described as a "civil coup d'État"), it took the form of a social revolt in its initial days,. Most of the rioters were jobless youth who believed Odinga was the only candidate who hearkened to their plight-and they were not all Luo, as stressed by Anne Cussac in the following chapter. The two epicentres of the demonstrations were Kisumu, in Nyanza Province, and the Kibera slums in Nairobi, both ODM strongholds. However, clashes between the rioters and security forces were soon worsened by fighting between ethnic gangs (Kikuyu against Luo; Kalenjin against Kikuyu...). In Nairobi, Kibera, Mathare, Kawangware, Korogocho, Dandora, Huruma and Kariobangi slums were engulfed by a wave of riots for several days. These attacks, which were initially ethnically motivated gave way to blind destruction. The protests became criminal, with gangs taking advantage of the crisis to loot and rape.

8 From January 2008, violence rocked the Rift Valley in Kericho and Eldoret then Naivasha and Nakuru. During inter-ethnic clashes, apart from the destruction of movable and fixed property as well as murders, there was a distinct desire displayed to spread terror by choosing soft targets (pregnant women, children and newly-born babies, the disabled). The use of machetes, knives or iron bars, recourse to killings and rape, were some of the cruel means of reminding the "enemy" community that 
anything was possible. ${ }^{10}$ The intervention by Mungiki militia, known for its extreme violence, undoubtedly made tempers flare. This could have encouraged a backlash of similar excesses by adversaries. ${ }^{11}$

9 The violence thus manifested itself in several dynamics: police repression of ODM supporters and gangs of looters, with a prevailing shoot-to-kill order, ${ }^{12}$ militia action on political orders (Mungiki as well as Kalenjin, Luo and to a lesser extent Kisii militia); operations of ad hoc vigilante groups carefully created to adhere to ethnic criteria; exactions by groups of thugs who sometimes passed for militia or vigilante groups; and settling of personal scores between groups or individuals taking advantage of the situation to grab or destroy rival business, or to take revenge on a tenant or landlord. ${ }^{13}$ Therefore, there was real confusion, including in the western parts of the country, Odinga's bedrock of support, where old feuds resurfaced, for example in the Rift Valley and the Mt Elgon area ${ }^{14}$. Violence was often between adolescents or young men for whom it meant defying traditional norms while questioning the political ability of the older generation in their respective communities. It is they who were responsible for erecting roadblocks and harassing motorists on an unprecedented scale.

Although the worst violence affected major urban centres, the rural areas were not spared either..$^{15}$ Parallel to the displacement of people witnessed in Eldoret, from Burnt Forest to the Uganda border, in Narok there were increased incidents of cattle rustling. In an area where this usually happens after the dry season, starting mid-March, when pastoralist communities need to "restock," these incidents occurred much earlier. As early as January and February, there were attacks in Lokwamosing, Samburu (Eastern Province), Lamuria, Rumuruti (Central Province), Cherangany, Naivasha and Koibatek (Rift Valley), which led to scores of deaths and theft of hundreds of heads of cattle. ${ }^{16}$ Whereas a delinquency of opportunism can be seen in the cattle rustling, it further appears that they underwent a transformation at the end of February, developing into deeper land and regional rivalries and showing that the communities involved (Samburu, Pokot, Maasai, Kikuyu, among others) were pursuing medium-term strategies.

11 Political leaders traded accusations over the violence using strongly emotive terms like "genocide" and "ethnic cleansing"-undoubtedly to draw the attention of the international community which was still traumatized by its failure during the 1994 Rwandan genocide.

\section{Confusion, ethnicity, tribalism, regionalism}

In many ways Kenya's democratization process has been spectacular and rapid. Even though multiparty politics did not lead to an immediate political transition, political expression has quickly gained ground. There has been tolerance and even encouragement in some cases for public expression without the danger of harassment by security forces. But this freedom is fragile as witnessed in the intimidation of human rights organization leaders during the month of January 2008.

The 2002 elections brought political transition along with Kibaki's victory. ${ }^{17}$ With the hopes that were raised, these elections masked a number of democratic shortcomings such as unfulfilled promises, political failures and corruption scandals, which characterized Kibaki's first term in office. Above all, the government proved to be incapable (or had little will) to directly face the main problems in the country. Among 
these were equitable land distribution and unemployment among the youth. Indeed, the violence in political and social relationships was a reminder of the bad memories of ethnicity, tribalism, land issues and Majimbo. ${ }^{18}$

Political debate in Kenya has been perpetually ethnicized since independence but as John Lonsdale points out, the chaos is not that easy to explain with reference to old "tribal" rivalries or cynical political calculations. ${ }^{19} \mathrm{~A}$ number of the current misunderstandings come from ambiguous relationships between British settlers and the Kikuyu, who were among the first victims and beneficiaries of colonization. In the 1950s, the Kikuyu rebellion movement, Mau Mau, and the numerous appropriations led to the Kikuyu being viewed as guardians of anti-colonial nationalism, relegating the emancipation efforts by ethnic communities to the background. ${ }^{20}$ Throughout Kenya's history there is a "moral ethnicity," which first developed among the small communities in the $19^{\text {th }}$ century then took root among the larger communities. This phenomenon is a system of internal regulation within each community built upon the notions of honour, patronage, generation, gender, poverty, wealth, property. ${ }^{21}$

Thus, "when the elites in Kenya go too far, their mistakes are largely interpreted as an excess in tribalism [...] politics of agreed, which offend the imagined moral economics of ethnic patronage in a relationship founded on production." ${ }^{22}$ However, as soon as Jomo Kenyatta came to power at independence, political actors resorted to exacerbated parochialism, instrumentalising segments of administration (provincial, district, authority and police), misappropriating public resources and diverting them to those close to them and to fund their election campaigns, organized "clean-up" operations, and under Daniel arap Moi, they carried out ethnic killings as well as financial mismanagement.

These practices, together with the government's propensity to capitalise on ethnicity, gave form to the imagined communities which crystallized and developed protection reflexes during crises. Thus, during the worst chaos at the beginning of 2008, a number of Kenyans withdrew into their ethnic cocoons, which they considered more reassuring -forming ethnic defence groups and refusing to talk to "enemies." What remains to be seen is how the internal tensions are negotiated within each ethnic community, particularly among the Kikuyu, Kalenjin and Luo. Another central aspect is that the anti-Kikuyu sentiments were greatly aggravated. The Kikuyu were accused of manipulating State apparatus, monopolizing the economy, controlling State firms and grabbing a lot of land. There were many fantasies about the Kikuyu community, which also mirrored its own fears of extermination if their representatives did not remain in power.

17 The January and February 2008 violence in the Rift Valley was largely a result of the old political strategies. During the colonial period, the Nandi and the Kipsigis were forcefully displaced to give way to White settlers. At independence, Kenyatta replaced the settlers with members of the Kikuyu community whom he resettled by the thousands. He appointed Moi, a Tugen, as Vice-President whose mission was to give positions to Nandi leaders on condition that they accepted an arrangement unfavourable to their community. Those opposed to the arrangement sometimes paid with their lives in political assassinations under the guise of accidents. When he ascended to power in $1978^{23}$, Moi sought to establish a new ethno-territorial order, closely associating ethnic community and administrative regions in order to create easily identifiable land and electoral areas. ${ }^{24}$ In 1992, as the first multiparty elections approached, the government organized violence aimed at displacing the Kikuyu. This 
was officially explained as restoring the land to its original owners but in reality, the government wanted to prevent Kikuyu voters from voting. Kikuyu resistance forced Moi to declare a state of emergency. A few years later, in 1996 and 1997, in order to avoid a repeat of this experience with mixed results, local leaders in northern Rift Valley helped many Kipsigis to settle on the land without displacing the Kikuyu who were still there by hiving off land from forests and government land. At the highest level of government, there was concern about re-drawing constituency boundaries to conform to the new settlements. These manipulations provoked fresh tension, hundreds of deaths and the displacement of tens of thousands others with the intervention of Kalenjin militia had already been causing chaos alongside the police. Then in 2003, the Kibaki government expelled thousands of Kalenjin farmers who had "illegally" settled in Molo District, the epicentre of conflicts for over ten years. Interethnic clashes in the Rift Valley also led to complex and sometimes contradictory dynamics: poverty, the desire to legally own land, ethnic rivalries and the reaction to government insensitivity to the immense disorder that it had contributed in creating.

The land question is paramount in understanding Kenyan politics. Despite significant urbanization, over $70 \%$ of the population live in rural areas. Additionally, "the agrarian economic policies and regional disparities significantly inform political rivalries, which inspire the fight for control of means of making land productive, a fundamental attribute for any kind of social upward mobility and an effective means of primitive accumulation in areas where land is most fertile." 25 The high population growth rate worsens the competition for land, particularly in the most attractive areas, with the highest rainfall (Central and Western Provinces).

The land issue has aggravated social, political and economic relations since the colonial period. In 2004, the Ndung'u report highlighted the inequalities; land grabbing, mismanagement and corruption in land allocation under the Kenyatta and Moi regimes, implicating former ministers of parliamentarians, judges, officers and other civil servants. ${ }^{26}$ Land distribution is heavily politicised and the central government, like the provincial administration is perpetually changing its principles-legal mechanisms in relation to land are now exceptionally complex with numerous favours accorded. ${ }^{27}$ The Ndung'u report, whose findings included falsified documents, excessive payments and the existence of fraudulent title deeds, emphasized the need for presidential intervention on the matter, especially concerning the degazetting of inalienable urban land. It was not surprising that most incidents of land manipulation occurred during the 1992, 1997 and 2002 electoral periods when land was used as political reward in a classical system of patronage. This also gave rise to the most classic cases of corruption -to recover funds, companies and administrations exchanged huge tracts of land without valuation. Similarly, protected areas were re-distributed with complete impunity. ${ }^{28}$

Public attention logically focused on community inequalities, particularly on land restructuring from which the Kikuyu benefited under Kenyatta and from which other communities benefited, starting with the Kalenjin under Moi. Alliances can thus be observed in the shadow of ethnic rivalries, like the Forum for Restoration of Democracy (Ford) which was formed at the beginning of the 1990s to protect the Kikuyu, Luo and Luhya from political scheming by Moi, who ensured that only those who swore allegiance to him remained in the Rift Valley. He accepted the introduction of multiparty politics but, on the other hand, did everything to demonstrate that the 
system could only lead to disorder. In this regard, the rekindling of the debate on Majimbo-the regional redistribution of power discussed by A. Cussac-could only fan the flames of the 2007 election campaigns.

\section{Disintegration: failing political strategies}

21 After the 2002 elections, many betrayals and failures undermined the credibility of the Kibaki regime. The National Rainbow Coalition (NARC), which propelled him to power, criticised his predecessor Moi of ethnicizing the State and impoverishing Kenyans, by approving intra- and inter-ethnic violence and allowing insecurity to flourish. For the opposition, the best response to the crisis was to form an interethnic structure. NARC agreed to the sharing of posts between the six principal ethnic leaders, Kibaki (Kikuyu), Odinga (Luo), Charity Ngilu (Kamba), George Saitoti (Maasai/Kikuyu), Kipruto arap Kirwa (Kalenjin), Kijana Wamalwa (Luhya) and Musyoka (Kamba). However, very soon after Kibaki's victory, it became evident that the Kikuyu networks sought to consolidate the power that had finally been recaptured. The inter-ethnic powersharing agreement was ignored and constitutional reform which was to lead to the creation of the prime minister's post was repeatedly postponed. It was then left to a parliamentary committee whose recommendations were not even heeded ${ }^{29}$ NARC then fell apart, giving way to new parties while others re-emerged. Thus, after a brief period of calm, the political game resumed with a shared ideal: the protection of an ethnic community's interests against its "enemies" by returning to its roots and through common destinies and social responsibilities.

Created in 2005 during the constitutional referendum campaigns, the ODM brought together politicians from various ethnic communities, who were disillusioned with NARC. Musyoka created his own structure while Odinga, a Luo, was able to gather around him Kalenjin, Luhya, Kamba, Mbeere and Arab leaders. Kibaki's secret hope to see as the creation of as many parties as the disillusioned politicians within NARC was thus dashed.

Beyond the reasoning of networks, Kenya as a State demonstrated an incapacity to define alternative forms of conflict management and resolution and was helpless in responding to crises. It showed its ineffectiveness in projecting a sense of national belonging strong enough to overcome ethnic divisions which led to an identity crisis and some sort of political schizophrenia. While the elite called for national identity in their rhetoric, they in fact used their positions to maintain their ethnic base. A political participation crisis is also emerging; the proliferation of political parties does not help in enhancing transparency and election rigging threatens to encourage voter apathy. Above all, beyond the events mentioned, the institutional crisis takes on other worrying trends. First, due to the opacity of the political system, the State's social and economic diffusion is weak and contributes to the freezing up of communities within their ethnic space. Furthermore, the State's "official" capacity to control instruments of violence has weakened. One may ask to what extent some sectors of the Kenyan state have fallen under the yoke of militias, which have become increasingly more difficult to contain by political leaders.

Electoral manipulation and the weakness (or bad faith) of the State in channelling the violence has indeed encouraged militias. Groups like Mungiki and Chinkororo (Kisii), which had never been dismantled, and other more transient ones either reformed or 
rehabilitated. Examples are Kamjesh, Talibans, Baghdad Boys (all Luo), as well as Kalenjin militias supported by Kalenjin business people and political figures in the Rift Valley, the People's Liberation Army and the Group of 41 (the 41 other ethnic communities apart from the Kikuyu), ${ }^{30}$ have for a long time edged out youth wings that had been activated by political parties during election campaigns. ${ }^{31}$ Currently, however, some groups have grown larger than their creators. ${ }^{32}$ The Mungiki example is the most outstanding. Its members were active at the beginning of the year in Central Province, the Rift Valley and Nairobi, with a clear slogan: "the time for revenge is now." ${ }^{33}$ They were also responsible for the chaos in Naivasha, Nakuru, Thika and Ruiru at the end of January. However, it appears that this group, secretly supported by leading Kikuyu political figures, is divided. Those within Mungiki who were paid by politicians close to the president to cause chaos are considered renegade by the others who are more concerned with central issues such as the land issue. In fact, in the cat and mouse game with the government, which sometimes uses the group and at others, represses it, there is no assurance that the militia group is the loser. Mungiki recruited massively during the events and thousands of members demonstrated within Nairobi City Centre to demand the release of one of its key leaders. This is a clear indication that the group can make itself either visible or invisible. ${ }^{34}$

There is a high risk that several of these militia groups could heavily arm themselves. Thus, while the Group of 41 may still be using machetes and arrows, the Mungiki have firearms. The criminalization of protests, with "rioters" infiltrating the protesters, together with the militarization of society, is expanding to fill in the vacuum left by the State. Those who suffer the most are the most disadvantaged fringes of the population, from the urban proletariat to the rural dispossessed. It is among these that the "recruitment sergeants" of the militia (jeshi, "armies" in Kiswahili) work, finding consenting prey among the excluded youth (from land resources, education system). This is because even though the free education programmes implemented by the Kibaki government has given of thousands of youth access to education, poverty has not reduced. One of the crucial issues remains employment of qualified youth, professional relegation, or those that are both unemployed and uneducated.

\section{Uncertainties: superficial pacification?}

Negotiations to resolve the crisis began early and could have been concluded by 10 January but the signing of the memorandum of understanding entitled "Principles of Agreement" by Kibaki and Raila in the presence of John Kufuor, the African Union mediator, Adam Wood, the British High Commissioner, together with American and French ambassadors (M. Ranneberger and E. Barbier), did not take place: Kibaki's PNU hardliners pressured him to abscond at the eleventh hour. ${ }^{35}$ The debates also became more serious and there was no end to the crisis as chaos spread across the country. Kofi Annan's arrival in Kenya on 22 January and the beginning of fresh negotiations on 28 January led to some progress. Each camp appointed a small committee bringing together hardliners and moderates. ${ }^{36}$ On 23 February, the creation of the post of Prime Minister for leader of the majority party in parliament and allocation of about 10 cabinet posts to ODM was adopted and after several days of pussy-footing, an accord was signed on 28 February. 

in diversion tactics, sending out signals of an enhanced authoritarianism. The appointment of a partial government on 8 January, the same day that John Kufuor arrived, was the first indication of this trend. It was confirmed by the inclusion of controversial figures like George Saitoti, John Michuki and Martha Karua. The appointment of Musyoka-who was third in the presidential race-to the post of VicePresident clearly demonstrated Kibaki's desire to seal up government positions, leaving only measly ministerial positions for any possible ODM appointees.

Under such conditions, international mediation was difficult. Kibaki, however, pointed out that the mediation was offensive or at the very least, useless since in his opinion, the situation had been contained and no illegality had been noted. The impression of indecision and tension which characterized the crisis resolution process was strengthened by mixed signals from some partners, especially Americans, ${ }^{37}$ disorder and repeated postponement in the arrival dates of mediators and intermediaries, ${ }^{38}$ government attitude ${ }^{39}$ and even the assassination of ODM parliamentarians. ${ }^{40}$ The power relations were also complex: each camp had hardliners and it was unclear how far they were prepared to go and who were in conflict not only with their direct adversaries but also sometimes with their own more moderate allies. ${ }^{41}$ Away from the political circles, there was concern within the business community, which urged political leaders to speedily resolve the crisis. They even took part in the initial negotiations. The Kibaki government's economic objectives for 2007 had been extremely ambitious: $10 \%$ growth in the short-term and attaining the status of middleincome countries by 2030. However, the events of early 2008 undermined the economy and cast doubt on speedy recovery, especially because several donors would be obliged to reconsider their assistance. ${ }^{42}$

Despite the duration of the crisis, there were some encouraging signs. The parliamentary elections culminated in a convincing victory by ODM, with some unknown candidates flooring old regulars in government. Many ministers lost their seats and almost all of Kibaki's generals were kicked out of government through the ballot. During parliament's opening session on 15 January, ODM candidate, Kenneth Marende, was elected with 105 votes in the third round of voting (against 101 for the PNU candidate), amidst fears that ODM parliamentarians would be approached (meaning bribed or manipulated) by PNU emissaries to join them and ruin opposition parliamentary hopes. Finally, the civil society was very active in public debate and adopted positions that were both uncompromising (demanding Kibaki's resignation) ${ }^{43}$ and moderate (expressing desire to see the course of justice replace street protests). ${ }^{44}$ This was an expression of the civil society's competitive function as an interested party. ${ }^{45}$ Nevertheless, even though they were well established and organized, they still seemed incapable of weakening the government-in this regard, the situation has barely changed over the past ten years. ${ }^{46}$

Kenya was in the eye of the storm. ${ }^{47}$ Although normal life in Nairobi had resumed and the agreement signed on 28 February 2008 raised hopes of political appeasement, the situation remained unstable. With the immediate problems affecting the internally displaced people, continued clashes across the country, the difficulty in defining the necessary constitutional amendments for power-sharing, the challenge of peace was colossal. 


\section{BIBLIOGRAPHY}

ANDERSON, A. (2002). 'Vigilantes, violence and the politics of public order in Kenya.' African Affairs 101: 531-555.

CHARTON, H., MEDARD, C. (ed) (2007). Annuaire de l'Afrique orientale 2005. Paris: L'Harmattan. CONNAN, D. (2008). 'La 'société civile' des droits de l'homme et les élections kényanes de 2007: quête de légitimation politique et impuissance sociale.' Les Cahiers de l'Afrique de l'Est 37.

GOUX, M.-A. (2003). 'Guerre des loyers dans les bidonvilles de Nairobi.' Politique Africaine 91: 6882.

GRIGNON, F. (1998). 'La démocratisation au risque du débat? Territoires de la critique et imaginaires politiques au Kenya (1990-1995).' In D.-C. MARTIN (ed), Nouveaux langages du politique en Afrique orientale. Paris, Nairobi: Karthala, IFRA.

INTERNATIONAL CRISIS GROUP (ICG) (2008). ‘Kenya in Crisis.’ Africa Report 137.

KAGWANJA, P. (2008). ‘Breaking Kenya's impasse. Chaos or courts?’ African Policy Institute, Working paper.

KENYA HUMAN RIGHTS INSTITUTE. (2008). 'Civil Society Responses to the Kenyan Crisis.' Nairobi: KHRI.

KLOPP, J. (2002) 'Can moral ethnicity trump political liberalism? The struggle for land and nation in Kenya.' African Studies 61 (2): 269-294.

LONSDALE, J. (1996). 'Ethnicité morale et tribalisme politique.' Politique Africaine 61: 98-115.

LONSDALE, J. (2003). 'Le cas kényan: un débat moral et politique.' Politique Africaine 90: 17-36.

LONSDALE, J. (2004). 'Moral and Political Argument in Kenya.' In B.D. Eyoh and W. Kymlicka (eds), Ethnicity and Democracy in Africa. Oxford, Athens: James Currey, Ohio University Press (pp. 73-95).

MAUPEU, H. (2000). 'Vie et mort d'un groupe de pression électorale. L'exemple de Youth for KANU ‘92.” L’Afrique orientale. Paris, Pau, Nairobi: L’Harmattan, Crepao, IFRA (pp. 395-421).

MAUPEU, H., ANDERSON, D. (2003). ‘Kenya, la succession de Moi.' Politique Africaine 90: 5-16.

MAUPEU, H., LAFARGUE, J. (1998). 'La société civile kényane: entre résilience et résistance.' Politique Africaine 70: 61-73.

MEDARD, C. (2008). 'Les conflits 'ethniques' au Kenya: une question de votes ou de terres?' Afrique contemporaine 180: 62-74.

NDUNG'U, P. (2004). Report of the Commission of Inquiry into the Illegal/Irregular Allocation of Public Land. Nairobi: Government Printer.

POMMEROLLE, M.-E. (2006). 'Une mémoire vive: débats historiques et judiciaires sur la violence coloniale au Kenya.' Politique Africaine 102: 85-100.

SOUTHALL, R. (2005). 'The Ndung'u Report. Land and graft in Kenya.' Review of African Political Economy 32 (103): 142-151.

SYAGGA, P.M. (2006). 'Land ownership and uses in Kenya: policy prescriptions from an inequality perspective.' In SOCIETY FOR INTERNATIONAL DEVELOPMENT (SID), Readings on Inequality in Kenya. Sectoral Dynamics and Perspectives. Nairobi: SID East Africa (pp. 289-344). 
WIDNER, J. (1992). From “Harambee" to "Nyayo!" The Rise of a Party State in Kenya. Berkeley:

University of California Press.

\section{NOTES}

1. The Kikuyu make up about $22 \%$ of the population, Luhya $14 \%$, Luo $13 \%$, Kalenjin $12 \%$ and Kamba $11 \%$. Kenya has more than 40 ethnic communities, some of which are integrated in large communities. For example, the Kalenjin community was formed in the 1940s to bring together several ethnic communities (Kipsigis, Nandi, Tugen, Keiyo, Marakwet in particular) and came up a common standard dialect, initially referred to as Nandi.

2. According to the ECK, Kibaki (Party of National Unity-PNU) won the presidential election with 4,584,721 votes (46\%), against 4,352,903 (44\%) garnered by Odinga (Orange Democratic Movement, ODM) and 879,903 (9\%) garnered by Kalonzo Musyoka (ODMKenya, ODM-K). Voter turnout was estimated at $69 \%$. During the same elections, Kenyans elected their parliamentarians: ODM (99 seats) won by a landslide ahead of PNU (43 seats), ODM-K (16 seats) and Kenya African National Union (KANU), former single party, which saw its decline sealed (14 seats).

3. For the electoral map, refer to paper by Bernard Calas in this volume.

4. In reality, the initial riots, which had taken place on 29 December (in Kisumu, Kericho and in Nairobi's Kibera slums) involved youth who were exasperated by the ECK's postponements.

5. In February 2008, estimates put the number of internally displaced persons between 200,000 and 250,000 . It was not easy to count them because, strictly speaking, there was no IDP camp. The refugees were as varied as they were mobile as the IDPs moved around a lot.

6. Apart from getting a major part of its resources from tourism, whose season had already been ruined, Kenya is a regional supply hub (oil, food). Uganda, Rwanda and Burundi therefore experienced shortages. For initial figures, refer to R. Porhel, 'The economic consequences of the political crisis,' in this volume.

7. The methods mentioned were vote-buying during campaigns, intimidation during the election period, higher number of voters than those registered, voting by dead voters, theft and smuggling of ballot boxes (the official seal was sometimes replaced by adhesive tape...), changing of ballot papers, missing signatures of poll agents, sending of photocopies instead of originals of result documents, and finally the rewriting of results during final vote tallying.

8. The European Union Elections Observation Mission, 'Preliminary statement: doubts about the credibility of the presidential results hamper Kenya's democratic progress.' 1 January 2008; Commonwealth Secretariat, 'Kenya general election 27 December 2007: the report of the Commonwealth Observer Group.' January 2008; Kenya Elections Domestic Observation Forum, 'Preliminary statement and verdict of the 2007 Kenya's general elections.' 31 December 2007; East African Community Observer Mission, 'Report on the Kenya general elections, December 2007.' January 2008. 
9. The mobile phone was a key tool in the rumour propaganda (via SMS). Both the opposition and the government used it unsparingly weeks before, during and after the elections.

10. Early in January 2008, an arson attack on an Eldoret church in which scores of people perished was one of the most widely covered incidents by the media. Journalists published survivors' testimonies which talked of mutilation, escapes through the window. However, many acts of extreme violence, of which there was clear evidence, were not covered by the media, especially those that took place in Nairobi slums. The first detailed reports became public in February. See: Kenya Human Rights Institute, 'Civil Society Responses to the Kenyan Crisis.' Nairobi, February 2008. This report distinguishes spontaneous violence, militia activity, gender violence, reprisals and opportunistic violence; the report also revisits the threats issued by some groups, for example the Thagicu People's Redemption Movement, whose two main targets were 'traitors' of the Kikuyu community and human rights activists. Together with these were the 'anonymous' threats warning members of some ethnic communities to leave their homes. During election campaigns and the weeks that followed them, vernacular radios (Kass FM in Kalenjin, Inooro, Kameme and Coro in Kikuyu) broadcast programmes that encouraged ethnic chauvinism.

11. Mungiki, a Kikuyu militia formed in 1987 , is today the most structured group in the country. It is said to have 600,000 members, who, however, pursue different aims. Many Mungiki adherents, who are also "available," engage in politically commissioned operations and in various business ventures (controlling official or underworld markets). They go through a Kikuyu initiation ritual which gives their membership a religious basis. Refer to references cited by Anne Cussac.

12. There was also a possibility of police behaviour being ethnically-oriented: there were testimonies of Kikuyu police officers passively watching as members of the Luo community were assaulted (and vice versa)

13. This mainly applied to the slums. Refer to M.-A. Goux, 'Guerre des loyers dans les bidonvilles de Nairobi.' Politique Africaine, No 91, October 2003, pp. 68-82.

14. For more on these regional conflicts, refer to the papers by Claire Médard and Anne Cussac.

15. Refer to maps by drawn Bernard Calas (subsequent pages) to illustrate this.

16. See, for example, 'Four killed in clash,' The Standard, 26 February 2008.

17. For more about this period, refer to 'Le Kenya. Le contrat social à l'abandon' No 70 June 1998 and 'Le Kenya après Moi' No 90 June 2003, both published in Politique Africaine.

18. Majimbo originally stands for a federal system that enabled each region to have its own government. After being experimented at independence, it was abandoned but the idea gained currency during crises, like in the 1990s and the 2007 election campaigns during which candidate Odinga said it would be implemented if he was elected.

19. J. Lonsdale, 'Kenya: ethnicity, tribe and state.' 17 January 2008 , available on openDemocracy. URL: https://www.opendemocracy.net/en/ kenya_ethnicity_tribe_and_state/[archive].

20. Debates in Kenya and in Great Britain on the scale of the Mau Mau movement are far from over. Refer to, among others, the detailed biography in M.-E. Pommerolle, 
'Une mémoire vive: debats historiques et judiciaires sur la violence coloniale au Kenya.' Politique Africaine, June 2006, No 102, pp. 85-100.

21. Refer to J. Lonsdale, 'Ethnicité morale et tribalisme politique.' Politique Africaine, No 61, March 1996, pp. 98-115, and 'Moral and Political Argument in Kenya.' In Berman, D. Eyoh and W. Kymlicka (eds), Ethnicity and Democracy in Africa, Oxford, James Currey, Athens, Ohio University Press, 2004, pp. 73-95.

22. J. Lonsdale, 'Le cas kényan: un débat moral et politique.' Politique Africaine, No 90, June 2003, p. 19.

23. From the mid-1970s, several reports have shed light on the use of State resources to favour the Central Province (Kikuyu). Parliamentarians demanded better land distribution and change in economic policy but they were repressed or even assassinated. Upon Kenyatta's death in 1978, his vice-president, Daniel arap Moi managed to manipulate the divisions among the Kikuyu elite to overcome the opposition to his take-over, which was actually provided for in the constitution. Kibaki, who was then minister of finance, supported him. Cf. J. Widner, From "Harambee" to "Nyayo!" The Rise of a Party State in Kenya. Berkeley, University of California Press, 1992.

24. Concerning this process and its consequences, refer to J. Klopp, 'Can moral ethnicity trump political liberalism? The struggle for land and nation in Kenya.' African Studies, vol. 61, No. 2, 2002, pp. 269-294; C. Médard, 'Les conflits 'ethniques' au Kenya: une question de votes ou de terres?’ Afrique contemporaine, no. 180.

25. F. Grignon, 'La démocratisation au risque du débat? Territoires de la critique et imaginaires politiques au Kenya (1990-1995).' In D.-C. Martin (ed), Nouveau langages du politique en Afrique orientale, Paris, Karthala, Nairobi, IFRA, 1998, p. 32.

26. P. Ndung'u, Report of the Commission of Inquiry into the Illegal/Irregular Allocation of Public Land, Nairobi, Government Printer, December 2004. Also refer to R. Southall, 'The Ndung'u Report. Land and graft in Kenya.' Review of African Political Economy, vol. 32, No 103, 2005, pp. 142-151. The Commission, whose members were specialists drawn from relevant ministries, was appointed by Kibaki in June 2003.

27. There are three types of land: government land (former crown lands), land under community jurisdiction (trust lands, belonging to various ethnic communities, but managed by the provincial administration) and private land.

28. P. Ndung'u, Report of the Commission... op. cit.; P.M. Syagga, 'Land ownership and uses in Kenya: policy prescriptions from an inequality perspective.' In Society for International Development (SID), Readings on Inequality in Kenya. Sectoral Dynamics and Perspectives, Nairobi, SID East Africa, 2006, pp. 289-344.

29. For further readings on constitutional reform and the referendum against the government, refer to H. Charton and C. Médard (ed), Annuaire de l'Afrique orientale 2005, Paris, L'Harmattan, 2007, p. 59-128.

30. Irin, 'Kenya: armed and dangerous.' 22 February 2008. The last group, in particular, is said to be well organized, no doubt by former soldiers. Other militias can be mentioned like Mulungunipa Forest Group (South Coast, towards Kwale), Kosovo Boys (Luhya and Luo militia based in Kibera) and even the Sabaot Land Defence Force (SLDF), which is mentioned later in this volume by Claire Médard.

31. H. Maupeu, 'Vie et mort d'un groupe de pression électorale. L'exemple de Youth for KANU ‘92.” L'Afrique orientale 2000, Paris, L'Harmattan, Pau, Crepao, Nairobi, IFRA, 2000, pp. 395-421. 
32. There are still few comparative studies on these militias. D. Anderson, 'Vigilantes, violence and the politics of public order in Kenya.' African Affairs, No 101, 2002, pp. 531555.

33. Cited by International Crisis Group (ICG), Kenya in Crisis, Africa Report No 137, 21 February 2008, p. 14.

34. 'Mungiki demo takes city by surprise.' Daily Nation, 6 March 2008.

35. ICG, Kenya in Crisis, op. cit., pp. 21-22.

36. Ministers Karua and Ongeri and MP Kilonzo to represent the government and MPs Mudavadi, Ruto, Kosgei and Orengo to represent ODM.

37. The United States had indicated the day after the announcement of results that the elections had been free and fair. Two days later, they reviewed their position and Jendayi Frazer, Assistant Secretary of State for African Affairs, came to Nairobi as mediator. From then on, US intervention was either firm or moderate, and Condoleeza Rice's visit to Kenya on 17 February was a demonstration of the will to pacify the debates. It is also worth noting that at the same time (16-23 February), George W. Bush was in Tanzania to discuss the setting up of Africom, a US military base along the eastern coast of Africa.

38. Disorder because several former African presidents (Benjamin Mkapa, Ketumile Masire, Joaquim Chisssano), as well as Graca Machel, wife of Nelson Mandela, arrived "uninvited." Only Machel and Mkapa were involved in the negotiations; Ugandan President Museveni, who had invited himself at a time when rumours were rife about the presence of his army in western Kenya, was welcomed more warmly by Kibaki (military support to him was an option for Uganda, which would suffer if Kenya collapsed). Postponements were due to delays in the arrival of John Kufuor and Kofi Annan.

39. When Odinga, on 18 January, called for a stop to demonstrations and change of strategy (boycott of pro-government companies), the government announced it had set up a mediation committee whose members were Kibaki's close allies or very 'strategic' (head of delegation: Musyoka; members: Saitoti, Karua, Uhuru Kenyatta, AttorneyGeneral Amos Wako.). This committee never sat.

40. Mellitus Mugabe Were, MP for Embakasi (Nairobi) was shot dead on the night of 28 January; David Kimutai Too, MP for Ainamoi (near Eldoret), was gunned down by a policeman two days later.

41. People like Joseph Kamotho, Karua, Amos Kimunya, Michuki and Njenga Karume of PNU and Balala and Ruto of ODM stopped at nothing in their extremist game. In the ICG report cited above, two Kikuyus-Joe Wanjui and Nathaniel Kang'ethe-who controlled access to Kibaki, were also mentioned.

42. In 2007, the Kenya government together with 17 principal donors and civil society representatives adopted an economic assistance strategy, the Kenya Joint Assistance Strategy (KJAS), which set out three levels of funding (high, medium and low) depending on governance. The low level of funding would lead to a reduction of budgetary and sectoral assistance.

43. A petition signed at the beginning of 2008 by about $30 \mathrm{NGOs}$ (including the Law Society of Kenya and the Institute of Education for Democracy), which was perhaps too fiery, was not covered by the media. 
44. P. Kagwanja, 'Breaking Kenya's impasse. Chaos or courts?' African Policy Institute, Working paper, January 2008.

45. Refer to Kenya Human Rights Institute, Civil Society Responses., op.cit., which mentions activities of various civil society organizations (Amani Mashinani Initiative, Amani Focus, Africog) aimed at finding a solution to the crisis.

46. H. Maupeu and J. Lafargue, 'La société civile kényane: entre résilience et résistance.' Politique Africaine, No. 70, June 1998, pp. 61-73; D. Connan, 'La 'société civile'des droits de l'homme et les élections kényanes de 2007: quête de légitimation politique et impuissance sociale.' Les Cahiers de l'Afrique de l'Est (Nairobi), No. 37, 2008.

47. On 25 January 2008, the day after the Kibaki-Raila handshake witnessed by Kofi Annan, clashes continued in Kibera and Mathare. During the whole of February, violence was the order of the day in some slum areas while the western parts of the country lived in uncertainty, with gangs of youths blocking the road to Narok, Naivasha, Nakuru, Eldoret and Kericho.

\section{AUTHORS}

\section{JÉRÔME LAFARGUE}

Jérôme Lafargue is the deputy director of IFRA and a political scientist.

\section{MUSAMBAYI KATUMANGA}

Musambayi Katumanga is a lecturer in political science at the University of Nairobi. 